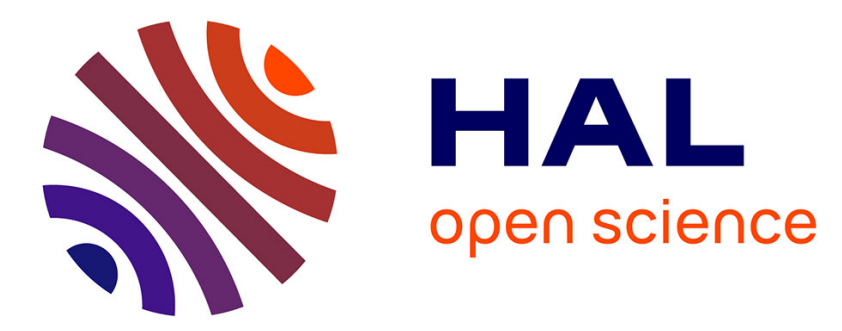

\title{
Unusual neon isotopic composition in Neoproterozoic sedimentary rocks: Fluorine bearing mineral contribution or trace of an impact event?
}

Deborah Chavrit, Manuel Moreira, David Fike, Frédéric Moynier

\section{To cite this version:}

Deborah Chavrit, Manuel Moreira, David Fike, Frédéric Moynier. Unusual neon isotopic composition in Neoproterozoic sedimentary rocks: Fluorine bearing mineral contribution or trace of an impact event?. Chemical Geology, 2019, 520, pp.52-59. 10.1016/j.chemgeo.2019.04.025 . insu-02916962

\section{HAL Id: insu-02916962 \\ https://hal-insu.archives-ouvertes.fr/insu-02916962}

Submitted on 22 Oct 2021

HAL is a multi-disciplinary open access archive for the deposit and dissemination of scientific research documents, whether they are published or not. The documents may come from teaching and research institutions in France or abroad, or from public or private research centers.
L'archive ouverte pluridisciplinaire HAL, est destinée au dépôt et à la diffusion de documents scientifiques de niveau recherche, publiés ou non, émanant des établissements d'enseignement et de recherche français ou étrangers, des laboratoires publics ou privés.

\section{(ㄷ)(1) $\$$}

Distributed under a Creative Commons Attribution - NonCommerciall 4.0 International 
$1 \quad$ Unusual neon isotopic composition in Neoproterozoic sedimentary rocks: fluorine bearing

2

3

4

5

6

7

8 9 10 11 12 13 14 15 16 17 18 19 20 9

\section{.}

mineral contribution or trace of an impact event?

$$
\text { Déborah Chavrit }^{1} \text {, Manuel A. Moreira }{ }^{*} \text {, David A. Fike }{ }^{2} \text {, Frédéric Moynier }{ }^{1,3}
$$

${ }^{1}$ Institut de Physique du Globe de Paris, Sorbonne Paris Cité, Univ Paris Diderot, CNRS, F75005 Paris, France

${ }^{2}$ Department of Earth and Planetary Sciences, Washington University, St Louis, Missouri 63130, USA

${ }^{3}$ Institut Universitaire de France, Paris, France

* corresponding author

Contacts:

Déborah Chavrit: deborahchavrit@gmail.com

Manuel A. Moreira: Moreira@ipgp.fr

David A. Fike: dfike@levee.wustl.edu

Frédéric Moynier: Moynier@ipgp.fr

\section{Keywords}

noble gas; Ediacaran sedimentary rocks; Ne-A; nucleogenic; fluorite; Acraman impact

\section{Highlights}

- Helium and neon isotopes have been measured in Huqf supergroup in Oman

- Neon shows a peculiar isotopic signature suggesting either a major extraterrestrial impact or a peculiar enrichment in fluorine 
30

31

32

33

34

35

36

37

38

39

40

41

42

43

44

45

46

47

48

49

50

51

52

53

54

55

56

57

\section{Abstract}

Extraterrestrial materials have $\mathrm{He}$ and $\mathrm{Ne}$ isotopic compositions that are distinct from those of the Earth's surface. In order to track the extraterrestrial material accreted onto Earth during the Ediacaran period, we have analyzed the $\mathrm{He}$ and $\mathrm{Ne}$ isotopic composition of thirteen sedimentary rocks in the age range $~ 550-600 \mathrm{Ma}$, coming from the Huqf supergroup in Oman for which carbon and sulfur isotopic data have been characterized previously.

${ }^{3} \mathrm{He} /{ }^{4} \mathrm{He}$ ratios range between $0.006 \pm 0.003$ and $0.27 \pm 0.01 \mathrm{R}_{\mathrm{A}}$, with $\mathrm{R}_{\mathrm{A}}$ being the atmospheric ratio. ${ }^{3} \mathrm{He} /{ }^{4} \mathrm{He}$ ratios show a positive relationship with ${ }^{3} \mathrm{He}$ contents ranging between 0.6 and 31 $\times 10^{-13} \mathrm{~cm}^{3}$ STP. $\mathrm{g}^{-1}$. The ${ }^{3} \mathrm{He}$ contents are within the literature data for 3 to $480 \mathrm{Myr}$ old samples with evidence of IDP ${ }^{3} \mathrm{He}$ (IDP for interplanetary dust particles), suggesting that extraterrestrial ${ }^{3} \mathrm{He}$ is still retained in such old samples.

${ }^{20} \mathrm{Ne} / 22 \mathrm{Ne}$ ratios are close to or below the modern atmospheric ratio of 9.8 with the minimum value equal to $9.05 \pm 0.03$. ${ }^{21} \mathrm{Ne} /{ }^{22} \mathrm{Ne}$ ratios show a high range of variation, going from $0.0345 \pm 0.0009$ to $0.0935 \pm 0.0023$. The Ne isotopic compositions follow a nucleogenic trend similar to that of crustal fluids from the literature and predicted continental crust. However, one sample (3404) shows an unusual $\mathrm{Ne}$ isotopic composition with a lower ${ }^{20} \mathrm{Ne} /{ }^{22} \mathrm{Ne}$ at similar ${ }^{21} \mathrm{Ne} / 22 \mathrm{Ne}$ compared to the other samples.

Two hypotheses can explain this singular Ne isotopic composition. First, it could be the result of a particular nucleogenic trend due to the presence of F-bearing minerals in this sample. SEMEDS elemental mapping showed that although F- and Ca-rich phases, which could correspond to fluorites, are present in sample 3404. However, their abundance of $\sim 0.15 \%$ seem too low to explain the unusual $\mathrm{Ne}$ isotopic composition. However, due to the high uncertainty of the calculations, we cannot totally rule out this hypothesis. Alternatively, the singular Ne isotopic composition could be due to the presence of a Ne-A component, a component characterizing presolar diamonds contained in chondrites. This would indicate that a major object impacted the Earth at the time the sediment was forming, between $\sim 600$ and $~ 550 \mathrm{Ma}$, which is coherent with the estimated age range of the Acraman impact in Australia. 


\section{Introduction}

The accretion of extraterrestrial material falling onto Earth can be tracked using geochemical tracers, which are more abundant and isotopically distinct in the extraterrestrial materials compared to the Earth's surface. For example, Ir concentrations, He isotopes and Os isotopes (e.g. (Peucker-Ehrenbrink 2001)) and Cr isotopes (Mougel et al., 2017) are particularly well suited geochemical tracers. Amongst those elements, He has the largest abundance variations between extraterrestrial and terrestrial material, with ${ }^{3} \mathrm{He}$ abundances and ${ }^{3} \mathrm{He} /{ }^{4} \mathrm{He}$ ratios in extraterrestrial material respectively $\sim 10^{9}$ and $\sim 10^{5}$ times higher than that of the Earth's crustal rocks (see review in (McGee and Mukhopadhyay, 2013)). Consequently, the measurements of He isotopes in marine sediments, or sedimentary rocks of different ages have been the subject of numerous studies for several decades, in order to track the accretion of extraterrestrial material onto Earth over geological timescales (e.g. (Amari and Ozima, 1988; Farley et al., 2006; Marcantonio et al., 1995; Murphy et al., 2010; Takayanagi and Ozima, 1987))

However, since He is an element with a high diffusivity (Hiyagon, 1994), it is likely to be partially or totally lost from the samples either during their entry into the atmosphere of after their deposition at the Earth's surface. For instance, among the extraterrestrial micrometeorites falling onto Earth, He can only be retained in the smallest ones (e.g. $<10 \mu \mathrm{m}$ ) because, due to their micrometric size, they experience less frictional heating during their entry in the Earth atmosphere than bigger objects (Farley et al., 1997).

Although the oldest samples with a record of extraterrestrial ${ }^{3} \mathrm{He}$ are $480 \mathrm{Ma}$ old carbonates (Patterson et al., 1998), due to its high diffusivity, He is likely to be partially or totally lost during its stay at the surface for millions of years. Thus, it is interesting to focus on Ne isotopes, because $\mathrm{Ne}$ is less sensitive to diffusion than He. According to the diffusion experiments of (Hiyagon, 1994), Ne would be retained in IDP at typical seafloor temperatures during the transit times of the ocean crust on the seafloor, unlike He, which would be significantly released from the IDP at these temperatures over million-year timescales.

Moreover, $\mathrm{Ne}$ isotopes have also distinct signatures in extraterrestrial materials compared to the Earth's surface. The Ne IDP signature is close to that of the Ne-B value (12.52 \pm 0.18 , (Black, 
1972), 12.73 \pm 0.02 , (Moreira, 2013; Moreira and Charnoz, 2016) and has been recently recorded in marine sediments together with IDP-derived He (Chavrit et al., 2016). Ne-B results from irradiation and sputtering processes in space (Moreira, 2013). As such, it preferentially is found in the outer $100 \mathrm{~nm}$ of objects and thus recovered in objects with a high surface to volume ratio such as IDP. Bigger objects such as meteorites can also include the Ne-B component if they derive from a regolith, however, they can additionally contain the Ne-A component (e.g. (Black, 1972; Pepin, 1967)), which has been recorded in pre-solar nano-diamonds (Huss and Lewis, 1994) and is particularly found in carbonaceous chondrites (see review in (Moreira, 2013)). Those two extraterrestrial signatures are distinct from the one that characterizes the material at the surface of the Earth. Combining $\mathrm{He}$ and $\mathrm{Ne}$ isotopes can allow to assess the amount of $\mathrm{He}$ lost from the samples (Chavrit et al., 2016). Thus, this could be used to trace the accretion of different size ranges of the extraterrestrial material falling onto Earth. Neon being less sensitive to diffusion than $\mathrm{He}$, it has the potential to trace different size ranges of extraterrestrial objects accreting onto Earth (from micrometeorites to meteorites).

In this study, we coupled $\mathrm{He}$ and $\mathrm{Ne}$ isotopic measurements in samples of $\sim 550$ to $\sim 600 \mathrm{Ma}$ old sedimentary rocks from the same location in Oman in order to trace the extraterrestrial material accretion during this time period.

\section{Samples and geological context}

The samples are 13 limestones, dolostones and calcareous shale from the Ediacaran-aged Huqf Supergroup in Oman. Samples come from MQR-1 well and span a depth range from 3228 $3936 \mathrm{~m}$, corresponding to the Khufai, Shuram, and Buah formations of the Nafun group. The samples are believed to have been deposited in the interval between $\sim 600 \mathrm{Ma}$ to $\sim 550 \mathrm{Ma}$ (Figure 1) (Bowring et al., 2003; Condon et al., 2005; Fike et al., 2006; Grotzinger et al., 1995; Le Guerroué et al., 2006), although the middle Ediacaran interval has notoriously poor chronostratigraphic resolution, frustrating attempts to link together records of environmental and ecological change over this critical interval of Earth history.

These samples have been previously characterized for their carbon and sulfur isotopic composition (Burns and Matter, 1993; Fike et al., 2006). The data record the largest known 
120

121

122

123

124

125

126

127

128

129

130

131

132

133

134

135

136

137

138

139

140

141

142

143

144

145

146

147

148

149

150

$\delta^{13} \mathrm{C}_{\text {carbonate }}$ negative excursion in Earth history, called the Shuram excursion, which is

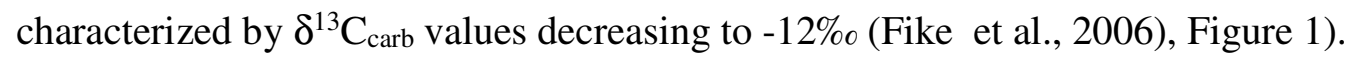

The origin of this excursion is still subject to debate. The Shuram excursion was first attributed to diagenetic alteration (Burns and Matter, 1993). However, methods to assess the diagenesis process have failed to validate this hypothesis (Le Guerroué, 2010). In addition, this excursion has been documented in multiple sites in the world, and it is more likely that the $\delta^{13} \mathrm{C}_{\text {carbonate }}$ values reflect a primary signal encoded into the sediments during deposition (Fike et al., 2006; Grotzinger et al., 2011 ; Le Guerroué and Cozzi, 2010).

\section{Methods}

\subsection{He and Ne isotopes measurements}

The sediment sample preparation is the same as in (Chavrit et al., 2016). Fractions of powdered samples weighting between 0.2 and $2 \mathrm{~g}$ (Table 1) were decarbonated on a heating plate at $60^{\circ} \mathrm{C}$ using $10 \%$ acetic acid. For noble gas analysis, the carbonate fraction of the samples has to be removed to improve the gas purification. After three rinsing with milliQ water, each residue was dried at $60^{\circ} \mathrm{C}$ and packed into 1 or $2 \mathrm{Al}$ foil packets, allowing for the measurement of duplicates. Sample 3404 was prepared twice. The packets were loaded into a sample tree made of Pyrex connected to the mass spectrometer. The extraction line was baked out at $\sim 120^{\circ} \mathrm{C}$ and sample tree baked out at $\sim 60^{\circ} \mathrm{C}$ for $\sim 12 \mathrm{~h}$ during pumping prior to the measurements. The gases were extracted from the samples under high vacuum using a furnace at $1200^{\circ} \mathrm{C}$. After purification, the ${ }^{3} \mathrm{He},{ }^{4} \mathrm{He},{ }^{20} \mathrm{Ne},{ }^{21} \mathrm{Ne}$ and ${ }^{22} \mathrm{Ne}$ were sequentially analyzed using the Noblesse mass spectrometer (Nu instruments) located at the Institut de Physique du Globe de Paris (IPGP), France, following the method described in (Chavrit et al., 2016). Together with an air standard for Ne, the isotopic compositions of the homemade gas standard used to calibrate the data are the following: ${ }^{3} \mathrm{He} /{ }^{4} \mathrm{He}=7.73 \mathrm{R}_{\mathrm{A}},{ }^{20} \mathrm{Ne} /{ }^{22} \mathrm{Ne}=9.94,{ }^{21} \mathrm{Ne} /{ }^{22} \mathrm{Ne}=0.0309$. On average, the furnace blank values, made at a temperature of $1200^{\circ} \mathrm{C}$, were $6 \times 10^{-9} \mathrm{~cm}^{3}$ STP for ${ }^{4} \mathrm{He}$ and $3.6 \times 10^{-12} \mathrm{~cm}^{3}$ STP for ${ }^{22} \mathrm{Ne}$.

Seven duplicates were analyzed in order to assess the reproducibility of the measurements. Duplicates of each sample were all from the same residual fraction which was split into several 
151

152

153

154

155

156

157

158

159

160

161

162

163

164

165

166

167

168

169

170

171

172

173

174

175

176

177

178

179

180

181

Al foil packets, except for sample 3404 which aliquots 2 and 3 were from a residual fraction different from that of aliquot 1 (Table 1).

In order to understand the origin of the Ne composition of the samples, we publish data of 3 Durango fluorapatites (Table 1) analyzed in 2006 by laser heating ( $\mathrm{Yb}$ doped fiber laser) using the ARESIBO mass spectrometer at the IPGP (Moreira and Allègre, 2002).

\section{Results}

The results are reported in Table 1. The non-carbonate fractions (NCF) range from $11 \%$ for the dolostone at $3428 \mathrm{~m}$ depth to $73 \%$ for the calcareous shale at $3722 \mathrm{~m}$ depth. ${ }^{3} \mathrm{He} /{ }^{4} \mathrm{He}$ ratios range between $0.006 \pm 0.003 \mathrm{R}_{\mathrm{A}}(3228 \# 1)$ and $0.27 \pm 0.01 \mathrm{R}_{\mathrm{A}}(3404 \# 2) . \mathrm{R}_{\mathrm{A}}$ is the atmospheric ratio, with a value of $1.384 \times 10^{-6}$ (Clarke et al., 1976b). The three highest ${ }^{3} \mathrm{He} /{ }^{4} \mathrm{He}$ ratios are similar and correspond to the 3 duplicates of 3404 , indicating a good reproducibility of the results. ${ }^{3} \mathrm{He}$ contents range between 0.6 and $31 \times 10^{-13} \mathrm{~cm}^{3}$ STP.g ${ }^{-1}$. They are in the same range as the data from the literature on samples that show evidence for an extraterrestrial ${ }^{3} \mathrm{He}$ contribution (Figure 2). In addition, our He data show a positive correlation between the ${ }^{3} \mathrm{He}$ content and the ${ }^{3} \mathrm{He} /{ }^{4} \mathrm{He}$ ratio, confirming the mixing of an extraterrestrial IDP component and a terrestrial component in the samples. ${ }^{3} \mathrm{He} /{ }^{4} \mathrm{He}$ positively correlates with ${ }^{4} \mathrm{He}$ and ${ }^{3} \mathrm{He}$ meaning that these two isotopes contribute to the variation of the ratio, which can be related both to the contribution of radiogenic ${ }^{4} \mathrm{He}$ from the terrestrial component and to the contribution of ${ }^{3} \mathrm{He}$ from the extraterrestrial component.

${ }^{20} \mathrm{Ne} / 22 \mathrm{Ne}$ ratios are close to or below the atmospheric ratio of 9.8 (Eberhardt et al., 1965), with the minimum values equal to $9.05 \pm 0.03$ for sample 3636 (Figure 3 ). ${ }^{21} \mathrm{Ne} /{ }^{22} \mathrm{Ne}$ ratios show a high range of variation, going from $0.0345 \pm 0.0009(3360 \# 1)$ to up to three times the atmospheric ratio of 0.0290 (Eberhardt et al., 1965) with the data of sample $3636\left({ }^{21} \mathrm{Ne} /{ }^{22} \mathrm{Ne}=0.0935 \pm 0.0023\right)$.

In Figure 1, different trends are highlighted in the evolution of the NCF and the noble gases isotopic ratios over time and depth. From $3936 \mathrm{~m}$ to $3722 \mathrm{~m}$, the NCF progressively increases from $16 \%$ to reach a maximum value of $73 \%$. Then, the NCF follows a constant decrease down to $11 \%$ at $3428 \mathrm{~m}$, followed by a relatively regular increase up to $30 \%$ at $3228 \mathrm{~m} .{ }^{3} \mathrm{He} /{ }^{4} \mathrm{He}$ ratios 
do not show a clear evolution, apart from two sharp positive peaks at $3826 \mathrm{~m}$ and $3404 \mathrm{~m}$. ${ }^{20} \mathrm{Ne} / 22 \mathrm{Ne}$ ratios and ${ }^{21} \mathrm{Ne} / 22 \mathrm{Ne}$ ratios show an opposite evolution. Whereas ${ }^{20} \mathrm{Ne} /{ }^{22} \mathrm{Ne}$ ratios decrease progressively from $3936 \mathrm{~m}$ to reach a minimum value at $3636 \mathrm{~m}$, the ${ }^{21} \mathrm{Ne} /{ }^{22} \mathrm{Ne}$ ratios increase. Between $3636 \mathrm{~m}$ and $3428 \mathrm{~m}$, the ${ }^{20} \mathrm{Ne} /{ }^{22} \mathrm{Ne}$ ratios increases whereas the ${ }^{21} \mathrm{Ne} /{ }^{22} \mathrm{Ne}$ ratio decreases. At $3404 \mathrm{~m}$, the ${ }^{20} \mathrm{Ne} / 22 \mathrm{Ne}$ ratios show a sharp negative spike, associated to a positive ${ }^{3} \mathrm{He} /{ }^{4} \mathrm{He}$ peak. Three duplicates of the sample at $3404 \mathrm{~m}$ show the same composition (Table 1) excluding a possible analytical problem during the measurement.

\section{Discussion}

In this part, we will highlight an unusual $\mathrm{Ne}$ isotopic signature. We will detail the two hypotheses that could explain such value.

\subsection{The recording of an unusual Ne signature}

In a ${ }^{20} \mathrm{Ne} /{ }^{22} \mathrm{Ne}$ vs ${ }^{21} \mathrm{Ne} /{ }^{22} \mathrm{Ne}$ diagram, our new data do not plot in the same area as previously analyzed terrestrial sediments (Figure 3), that showed evidence of IDP derived Ne (Chavrit et al., 2016). It does not necessarily mean that IDP are absent from the samples. More preferentially, the Ne IDP signal may be overprinted, as it is also the case for helium, because the samples contain much higher NCF than the samples of (Chavrit et al., 2016) (Annex Figure A1 of the supplementary material).

Except for the sample at $3404 \mathrm{~m}$, our samples fall into the field defined by crustal fluids (Holland et al., 2013; Kennedy et al., 1990; Lippmann-Pipke et al., 2011) or by the continental crust from the KTB drill in Germany (Drescher et al., 1998). Sample 3404 presents an unusual Ne isotopic composition, with a ${ }^{20} \mathrm{Ne} / 22 \mathrm{Ne}$ ratio lower than that of the other samples at similar ${ }^{21} \mathrm{Ne} /{ }^{22} \mathrm{Ne}$ ratio and falls outside this crustal fluid field. The three analyses of the Ne isotopic composition of this sample are in excellent agreement (Table 1, Figure 3) indicating that this signature is not an analytical artifact. In order to better understand this $\mathrm{Ne}$ isotopic composition, we have calculated the slope of the mixing line going through each sample and the air component in the Ne three isotopes diagram. In Figure 4, these slopes do not show a progressive evolution with depth of the samples while the $3404 \mathrm{~m}$ sample shows a strong negative spike. Consequently, this 
unusual $\mathrm{Ne}$ isotopic signature seems to be localized and to only affect the layer at $3404 \mathrm{~m}$. It corresponds to the late stage of the Shuram excursion, at a slope break where the $\delta^{13} \mathrm{C}$ starts to recover more rapidly, at the beginning of the Buah formation (Figure 1). In the following we are going to explore the two hypotheses that could explain such composition.

\subsection{A F-bearing mineral for the unusual Ne signature?}

\subsubsection{Neon nucleogenic production in Earth samples}

In the continental crust, the radioactive decay of ${ }^{235,238} \mathrm{U}$ and ${ }^{232} \mathrm{Th}$ produce $\alpha$ particles, most of which stabilize in radiogenic ${ }^{4} \mathrm{He}$. The other $\alpha$ particles react with surroundings atomic nuclei, such as ${ }^{17} \mathrm{O},{ }^{18} \mathrm{O}$ and ${ }^{19} \mathrm{~F}$ isotopes to produce respectively nucleogenic ${ }^{20} \mathrm{Ne},{ }^{21} \mathrm{Ne}$ and ${ }^{22} \mathrm{Ne}$ (Figure 5). ${ }^{20} \mathrm{Ne},{ }^{21} \mathrm{Ne}$ and ${ }^{22} \mathrm{Ne}$ are also produced by neutron activation from ${ }^{23} \mathrm{Na},{ }^{24} \mathrm{Mg},{ }^{25} \mathrm{Mg}$ (Figure 5), however, these reactions account for less than $1 \%$ of the Ne production in the crust (Yatsevich and Honda, 1997). Based on the previous works of (Yatsevich and Honda, 1997) and (Hünemohr, 1989), production rates (in $\mathrm{cm}^{3} \mathrm{STP} \mathrm{g}^{-1} \cdot \mathrm{yr}^{-1}$ ) have been empirically quantified by (Ballentine and Burnard, 2002) as a function of the $\mathrm{U}$, Th and F contents (in ppm) and $\mathrm{O}, \mathrm{Mg}$, $\mathrm{Na}$ contents (in wt\%), with the following equations:

$$
\begin{aligned}
{ }^{20} \mathrm{Ne} \text { produced } & =(6.39[\mathrm{U}]+0.770[\mathrm{Th}])(0.0226[\mathrm{O}]+0.0022[\mathrm{Na}]) \times 10^{-22} \\
{ }^{21} \mathrm{Ne} \text { produced } & =\{(1.48[\mathrm{U}]+0.186[\mathrm{Th}])[\mathrm{O}]+(0.105[\mathrm{U}]+0.0179[\mathrm{Th}])[\mathrm{Mg}]\} \times 10^{-22} \\
{ }^{22} \mathrm{Ne} \text { produced } & =\{(3.06[\mathrm{U}]+0.417[\mathrm{Th}])[\mathrm{F}]+(4.20[\mathrm{U}]+0.663[\mathrm{Th}])[\mathrm{Mg}]\} \times 10^{-24}
\end{aligned}
$$

These equations show that the nucleogenic ${ }^{20} \mathrm{Ne} /{ }^{22} \mathrm{Ne}$ and ${ }^{21} \mathrm{Ne} /{ }^{22} \mathrm{Ne}$ production ratios are principally dependent on the $\mathrm{O} / \mathrm{F}$ ratios of the samples as $\mathrm{F}$ in involved only on the production of ${ }^{22} \mathrm{Ne}$. As $\mathrm{Mg}$ is a major element, its natural variations of concentration remain small compared to other trace elements such as $\mathrm{F}, \mathrm{U}$, Th. Variable $\mathrm{O} / \mathrm{F}$ ratios will have the effect to change the slopes of the mixing lines between the atmospheric endmember and the nucleogenic endmember in a graph ${ }^{20} \mathrm{Ne} /{ }^{22} \mathrm{Ne}$ versus ${ }^{21} \mathrm{Ne} /{ }^{22} \mathrm{Ne}$ (Figure 3).

The continental crust nucleogenic trend predicted by (Yatsevich and Honda, 1997) corresponds to a $\mathrm{O} / \mathrm{F}$ ratio of 752 (atomic ratio) (Ballentine and Burnard, 2002), according to the previous 
equations (1), (2) and (3). Archean fluids also follow a similar trend (Holland et al., 2013). Crustal fluids data of (Kennedy et al., 1990) lie on a trend with $\mathrm{O} / \mathrm{F}=113$ (Ballentine and Burnard, 2002). Almost all data from the literature, being crustal fluids of different ages, plot in the field with an $\mathrm{O} / \mathrm{F}$ ratio ranging from $\sim 113$ to $\sim 752$ (Figure 3).

After equations (1), (2) and (3), O/F ratios lower than 113 can be obtained for minerals very rich in $\mathrm{F}$ and/or very poor in oxygen. It is the case for a full range of accessory minerals, for example bastnäsite, containing $7.35 \mathrm{wt} \% \mathrm{~F}(\mathrm{O} / \mathrm{F}=4)$, or fergusonite $(\mathrm{F}=1.42 \mathrm{wt} \%, \mathrm{O} / \mathrm{F}=34)($ Ballentine and Burnard, 2002; Eikenberg et al., 1993; Hünemohr, 1989). It has the consequence of significantly shifting common nucleogenic trends towards trends with more negative slopes (Figure 3). Some major minerals can also present a low $\mathrm{O} / \mathrm{F}$ ratio. For example, fluorite $\left(\mathrm{CaF}_{2}\right)$, which does not contain any oxygen, is characterized by an $\mathrm{O} / \mathrm{F}$ ratio of 0 . Fluorapatite, the most common phosphate mineral in the environment is also characterized by a low $\mathrm{O} / \mathrm{F}(\mathrm{O} / \mathrm{F}=12)$. Neon isotopic measurements of the Durango fluorapatite (Table 1, Figure 3) are in agreement with the nucleogenic trend defined using $\mathrm{O} / \mathrm{F}=12$, determined theoretically using the mineral formula $\left(\mathrm{Ca}_{5}\left(\mathrm{PO}_{4}\right)_{3} \mathrm{~F}\right)$, suggesting that the empirical equations are reliable to estimate the ${ }^{20} \mathrm{Ne} /{ }^{22} \mathrm{Ne}$ and ${ }^{21} \mathrm{Ne} / 22 \mathrm{Ne}$ production ratios and consequently the nucleogenic trends.

\subsubsection{Unusual Ne signature: a particular terrestrial nucleogenic trend?}

Except one sample, our sedimentary rock samples fall into the same field as the one of crustal fluids, corresponding to an O/F ratio ranging from $\sim 113$ to $\sim 752$ (Figure 3). For these samples, the extents of the ${ }^{21} \mathrm{Ne} /{ }^{22} \mathrm{Ne}$ ratios and ${ }^{22} \mathrm{Ne}$ contents are related to the non-carbonate fraction (Annex Figure A1 of the supplementary material), an expected correlation since $\mathrm{Ne}$ is produced by nuclear reactions of isotopes present in the detrital fraction of the samples, containing $U$ and Th.

On the other hand, an $\mathrm{O} / \mathrm{F}$ equal to $\sim 34$ is required to explain the composition of the $3404 \mathrm{~m}$ deep sample (Figure 3). An O/F ratio of 34 corresponds to the fergusonite $(\mathrm{O}=40.4 \mathrm{wt} \%, \mathrm{~F}=1.42$ wt\%), an accessory mineral phase. However, this sample could not only be composed of this mineral, since it contains $85 \%$ carbonates (Table 1). Alternatively, it would be more probable that the singular $\mathrm{Ne}$ isotopic composition could be the result of a mixing between an endmember 
273

with production ratios similar to the one fitting the literature data and all the samples from this study except at $3404 \mathrm{~m}$, that is with $113 \leq \mathrm{O} / \mathrm{F} \leq 752$ and another endmember characterized by a mineral phase with a $\mathrm{O} / \mathrm{F}$ lower than 34 such as fluorapatite or fluorite characterized respectively by $\mathrm{O} / \mathrm{F}=12$ and $\mathrm{O} / \mathrm{F}=0$ (Figure 3). The Ne isotopic compositions of these two endmembers can be apprehended. The predicted crust production ratios are the following: ${ }^{20} \mathrm{Ne} /{ }^{22} \mathrm{Ne}=0.36$, ${ }^{21} \mathrm{Ne} / 22 \mathrm{Ne}=3.67$ (Yatsevich and Honda, 1997), corresponding to an O/F ratio of 752 (Figure 3). For the other endmember, we use the isotopic neon production ratios of fluorapatite $\left({ }^{20} \mathrm{Ne} /{ }^{22} \mathrm{Ne}=0.0043 ;{ }^{21} \mathrm{Ne} /{ }^{22} \mathrm{Ne}=0.0458\right)$ and fluorite $\left({ }^{20} \mathrm{Ne} /{ }^{22} \mathrm{Ne}=0 ;{ }^{21} \mathrm{Ne} /{ }^{22} \mathrm{Ne}=0\right)$ that we calculated using the elemental proportion calculated after their mineral formulae and equations (1), (2) and (3). The details of our calculations are provided in the Annex 2 of the supplementary material. After our calculations, the decrease of the O/F ratio from 752 down to 34 in order to fit the data points of sample 3404 would require the presence of $96 \%{ }^{22} \mathrm{Ne}$ derived from fluorite or $98 \%{ }^{22} \mathrm{Ne}$ derived from fluorapatite in the sample.

Using equations (1), (2) and (3), we estimate that for $600 \mathrm{Ma}$ old fluorites and fluorapatites, the produced ${ }^{22} \mathrm{Ne}$ concentration is $\sim 2$ orders of magnitude higher than the ${ }^{22} \mathrm{Ne}$ concentration of the samples from this study. It implies that $\sim 0.4$ to $37 \%$ fluorite, depending on the $\mathrm{U}$ and Th content of the fluorine-bearing phase, would be sufficient to account for the Ne composition of the $\sim 600$ Ma old sample 3404. If the signal came exclusively from fluorapatite, this mineral would need to have an abundance of $0.3-16 \%$. To evaluate the presence of $\mathrm{F}$ in several of the samples, we performed SEM-EDS elemental mapping for some of the residual fractions of the samples (noncarbonate fractions) including sample 3404 (See Annex 3 of the supplementary material for the details on the SEM measurements). The maps show some spots with a F-enrichment (Figure 6). It is not possible to get reliable quantification of the data because the samples were powders that were consequently not flat and Au-coated. Nevertheless, the decarbonated fraction of sample 3404 is the one which seems to visually contain the most abundant F-bearing phases amongst the 5 analyzed samples (Figure 6), particularly compared to sample 3428 which has a similar amount of non-carbonate fraction. From these observations, it is thus possible that sample 3404 has an $\mathrm{O} / \mathrm{F}$ ratio lower than those of the other samples. However, a precise quantification is required to determine if its $\mathrm{O} / \mathrm{F}$ ratio is low enough to explain its peculiar Ne composition. This can be assessed using theoretical calculations. The F-rich spots in sample 3404 are associated with Caenrichments (Figure 6, Annex Figure A2 of the supplementary material), suggesting that these 
phases are fluorites. We did not see any P peak associated with F peak in the spectra that could witness the presence of fluorapatite. If we assume that all the F-rich phases in sample 3404 were fluorite, we can estimate that $\sim 1$ wt. $\%$ of fluorite is present in the $\sim 15$ wt. $\%$ of the noncarbonate fraction of sample 3404 (Table 1) analyzed with SEM-EDS (Figure 6), thus corresponding to $0.15 \mathrm{wt} . \%$ of fluorite in the whole-rock sample. This first order calculation gives a value too low to explain the composition of sample 3404. However, our calculations and SEM measurements are not precise enough to be definite, especially because fluorite can contain highly variable amounts of $U$ and Th and that we did not consider any ejection factor of $\alpha$ particles, which is dependent on the crystal size (Gautheron et al., 2006). Measurements of fluorite crystals of different ages and sizes are needed to better evaluate the nucleogenic $\mathrm{Ne}$ production in this mineral, in order to definitely test whether fluorite is responsible for the peculiar Ne composition of sample 3404.

\subsection{A meteoritic origin for the unusual Ne signature?}

\subsubsection{The Ne-A component in sedimentary rocks}

In this study, the layer at $3404 \mathrm{~m}$ is characterized by an unusual $\mathrm{Ne}$ isotopic signature, with ${ }^{20} \mathrm{Ne} / 22 \mathrm{Ne}=9.13-9.25$ and ${ }^{21} \mathrm{Ne} /{ }^{22}=0.0368-0.0373$ (Table 1). If this composition cannot be explained by a nucleogenic trend (see previous section, 5.2), alternatively, it could be the result of mixing three distinct components: air, "common" nucleogenic Ne and Ne-A (Figure 3). The $\mathrm{Ne}-\mathrm{A}$ component is a component present in meteorites, mainly in carbonaceous chondrites (see review in (Moreira, 2013), with a distinct signature $\left({ }^{20} \mathrm{Ne} /{ }^{22} \mathrm{Ne}=8.500 \pm 0.057\right.$, ${ }^{21} \mathrm{Ne} / 22 \mathrm{Ne}=0.036 \pm 0.001$, (Huss and Lewis, 1994) compared to those of the Earth's surface, such as air and crustal fluids (Figure 3). Consequently, a ${ }^{20} \mathrm{Ne} /{ }^{22} \mathrm{Ne}$ ratio below the air value and a relatively low ${ }^{21} \mathrm{Ne} / 22 \mathrm{Ne}$ ratio in a sedimentary rock, such as in sample 3404, open the question of the presence of a meteorite component in this sample. Such a component would imply that an impact occurred on Earth at the time the sediment formed and that pre-solar nano-diamonds contained in the bolide survived the impact, allowing this volatile element and thus the Ne-A component to be trapped in the sediments. Darrah et al. measured a Ne isotopic composition in a 
$65 \mathrm{Ma}$ old sediment from the LL-44 GPC-3 deep sea sediment core, with ${ }^{20} \mathrm{Ne} /{ }^{22} \mathrm{Ne}=8.85$ and ${ }^{21} \mathrm{Ne} / 22 \mathrm{Ne}=0.025(\mathrm{n}=2)$, values very different from those characterizing their other samples (Darrah and Poreda, 2012). This composition is close to the Ne-A value. As evidenced from platinum group elements excesses and the presence of the large Chicxulub crater, the Earth underwent a large meteorite impact 65 Ma ago (e.g. (Alvarez et al., 1980; Hildebrand et al., 1991; Sharpton et al., 1992). Therefore, the presence of a Ne-A component in the sediments may be a witness of a major meteoritic impact. This peculiar neon isotopic signature is also associated to the highest ${ }^{3} \mathrm{He} /{ }^{4} \mathrm{He}$ ratio $(\sim 0.27 \mathrm{Ra})$, although helium alone could be used to trace an impactor (Mukhopadhyay et al., 2001).

It is extremely difficult to estimate the mass fraction of presolar nanodiamonds in the samples, as this deals with concentrations in the different endmembers, which are not well constrained. However, Huss et al. (Huss and Lewis, 1994) provide a typical concentration of ${ }^{22} \mathrm{Ne}$ of $\sim 810^{-6}$ $\mathrm{cm}^{3}$ STP. $\mathrm{g}^{-1}$ for the carrier of Ne-A (pre-solar diamonds). If we assume a simple binary mixing between a terrestrial and extraterrestrial neon, we can calculate the mass fraction of extraterrestrial material in the NCF of sample 3404 as follow:

$$
\beta=\frac{R_{\text {measured }}-R_{\text {terrestrial }}}{R_{\text {diamonds }}-R_{\text {terrestrial }}} \sim 0.5=\frac{C_{\text {diamonds }} M_{\text {diamonds }}}{C_{\text {measured }} M_{\text {measured }}} \sim \frac{810^{-6}}{210^{-10}} \frac{M_{\text {diamonds }}}{M_{\text {measured }}}
$$

Where $\mathrm{R}$ is the ${ }^{20} \mathrm{Ne} /{ }^{22} \mathrm{Ne}$ ratio. The term 0.5 is roughly estimated from Figure 3. We can therefore estimate a mass fraction of presolar diamonds carrying the neon-A signature in the NCF to be $\sim 10 \mathrm{ppm}$. This however assumes that no neon loss has occurred and that the neon concentrations in nanodiamonds are well preserved during the impact and after. Using the ${ }^{3} \mathrm{He} /{ }^{22} \mathrm{Ne}$ of $\sim 1$ measured in presolar nanodiamonds, by Huss and Lewis (1994) we can also estimate the theoretical extraterrestrial ${ }^{3} \mathrm{He}$ within sample 3404 . The calculation above suggests that half of the ${ }^{22} \mathrm{Ne}\left(\sim 10^{-10} \mathrm{ccSTP} / \mathrm{g}\right)$ in the NCF should be of extraterrestrial origin and therefore the sample should contain $\sim 10^{-10} \mathrm{ccSTP} / \mathrm{g}$ of extraterrestrial ${ }^{3} \mathrm{He}$ in the NCF. The NCF of sample 3404 contains only $\sim 510^{-12} \mathrm{ccSTP} / \mathrm{g}$ of total ${ }^{3} \mathrm{He}$, much lower than expected from neon isotope calculation, suggesting either helium was lost during the impact or after deposition.

\subsubsection{Evidence of an impact at the time sample $3404 \mathrm{~m}$ formed?}


The presence of a Ne-A component would imply that an object impacted the Earth and that the sedimentary rock at $3404 \mathrm{~m}$ would have included some ejecta containing the Ne-A component during its formation. This could be related to the Acraman impact. The Acraman Lake in South Australia is part of a deeply eroded impact structure in South Australia (Williams, 1986, 1994) with an estimated original diameter of $\sim 40-90 \mathrm{~km}$ (Haines, 2005), making it one of the ten largest impact structures on Earth. The presence of ice-rafted material in layers directly below and above the ejecta layer related to the Acraman impact structure, suggests that the Acraman impact occurred during a phase of glaciation (Gostin et al., 2010). This could possibly correspond to the Gaskiers glaciation dated at 580 Ma (Bowring et al., 2003; Pu et al., 2016) using $\mathrm{U}-\mathrm{Pb}$ zircon geochronology on tuffs bracketing glacial diamictites. Similarly, (Walter et al., 2000) suggested an age of $578 \mathrm{Ma}$ for the Acraman impact using chemostratigraphic correlation. However, the Acraman impact lacks a robust isotopic age for the ejecta layers due to difficulties of dating (Schmieder et al., 2015). Thus, the age of the Acraman impact can only be loosely constrained in the Ediacaran period between $\sim 541$ and $\sim 635$ Ma by stratigraphic bracketing (Schmieder et al., 2015).

The layer at $3404 \mathrm{~m}$, possibly containing the signature of Ne-A component, is not directly dated. Nevertheless, the age range for the Nafun group layers has been assessed through correlations to other sections (Fike et al., 2006) with U-Pb zircon ages obtained on ash beds (Bowring et al., 2003; Pu et al., 2016). The unconformity below the $3836 \mathrm{~m}$ layer, at the base of the Shuram formation, probably includes the time period of the -580 Ma Gaskiers glaciation, based on stratigraphic correlation (Bowring et al., 2003; Fike et al., 2006). The recovery of the Shuram excursion $(3300 \mathrm{~m}$ ) is thought to have been completed by $\sim 550 \mathrm{Ma}$ (Condon et al., 2005). Thus, the sample at $3404 \mathrm{~m}$ should have an age between $\sim 580$ and $550 \mathrm{Ma}$ (Figure 1). However, an alternative view based on thermal subsidence curves to transform stratigraphic thicknesses of the Nafun Group into time suggests that the basal Shuram is 600 Myr (Le Guerroué et al., 2006). In this scenario, the base on the Buah formation, where the layer at 3404 is located, might have an age of 575-570 Ma (Le Guerroué et al., 2006), close to the Acraman impact age of $578 \mathrm{Ma}$ determined by (Walter et al., 2000).

The estimated age range for the Acraman impact is thus consistent with the estimated time range for the formation of the sample at $3404 \mathrm{~m}$. Thus, the presence of an impact-derived Ne-A component present in this sample that would witness an impact event is possible. 
However, more precise age constraints for both the Acraman impact and for the deposition of the Nafun group layers are required to confirm the validity of this hypothesis.

398

399

400

401

402

403

404

405

406

407

408

409

410

411

412

413

414

415

416

417

418

419

420

421

422

423

424

425

\section{Conclusion}

We have analyzed $\mathrm{He}$ and $\mathrm{Ne}$ isotopes in Ediacaran sedimentary rocks from the Nafun Group strata, Sultanate of Oman that are believed to have been deposited between $\sim 600-580$ and $~ 550$ Ma. Extraterrestrial He is still present in these samples and is in similar amounts to that found in 3 to 480 Myr old samples. However, we were unable to detect $\mathrm{Ne}$ isotopic composition of interplanetary dust, unlike other data (Chavrit et al., 2016). This may be related to the higher non-carbonate fraction in these samples as compared to previously published samples. Except for one sample, the Ne isotopic composition follows a common nucleogenic trend, similar to those defined by crustal fluids from the literature and the one predicted for the continental crust. However, the other sample, from basal strata of the Buah formation, shows an unusual $\mathrm{Ne}$ isotopic composition that can be explained by two hypotheses.

First, a singular nucleogenic trend deviating from the common nucleogenic trend could explain the data. This would be the case if the sample contains a fluorine bearing mineral, such as fluorite or fluorapatite, in amounts ranging respectively from 0.4 to $37 \%$ and 0.3 to $16 \%$ by mass, depending on the $U$ and Th contents of these minerals. Using SEM, we measured that the sample contains $\sim 0.15 \%$ fluorine and calcium rich phases. However, our estimates indicate that this abundance is lower than the minimum fluorite proportion required to explain its singular $\mathrm{Ne}$ composition. Nevertheless, our calculations are based on theoretical predictions and greatly rely on the amount on $\mathrm{U}$ and $\mathrm{Th}$ used, which can lead to very different yields of ${ }^{20} \mathrm{Ne}$ produced after $600 \mathrm{Ma}$, and thus lead to a wide range for the required proportion of fluorine-bearing mineral contained in this singular sample.

The other alternative is that this unusual $\mathrm{Ne}$ isotopic composition is related to the assimilation of an extraterrestrial Ne-A component in this sample. This could be the result of a significant meteoritic impact and, if so, would indicate that this highly volatile element was not lost to the atmosphere upon the impact. This would be consistent with the Neoproterozoic Acraman impact 
in Australia. However, the ages of both the impact event and the deposition of the basal Buah Formation that contains the singular $\mathrm{Ne}$ isotopic composition are loosely constrained and more precise ages are required to validate the impact hypothesis for the origin of the $\mathrm{Ne}$ signal observed here.

For the time being, it is not possible to definitely rule out or validate one of the two hypotheses. Future work will be to investigate the $\mathrm{Ne}$ isotopic composition of fluorine bearing minerals of different ages to better assess their nucleogenic production over time. Sedimentary rocks containing impact ejecta should also be analyzed.

Due to its signature in chondrites, Ne can potentially be an indicator of meteoritic impact in sedimentary rocks. However, this study shows that in samples that are hundreds of million years old, small amounts of F-bearing minerals can significantly affect the resulting $\mathrm{Ne}$ isotopic composition. Thus, it is essential to consider the nucleogenic Ne production, in deciphering the $\mathrm{Ne}$ isotopic composition in sedimentary rocks, especially for very old ones.

\section{Acknowledgments}

We thank the Oman Ministry of Oil and Gas for permission to publish this paper. We thank Stephan Borensztajn for assistance during with the SEM measurements and Cécile Gautheron for providing the Durango fluorapatite. FM thanks the European Research Council under the European Community's H2020 framework program/ERC grant agreement \# 637503 (Pristine), the Agence Nationale de la Recherche for a chaire d'Excellence Sorbonne Paris Cité (IDEX13C445) and the Plateform PARI. FM and MM thank the UnivEarthS Labex program (ANR-10-LABX-0023 and ANR-11-IDEX-0005-02). P. Sarda, J. Hopp and the two other anonymous reviewers are thanked for their constructive reviews. This is IPGP contribution number 4027.

\section{References}


Alvarez, L.W., Alvarez, W., Asaro , F. and Michel , H.V. (1980) Extraterrestrial cause for the Cretaceous-Tertiary extinction. Science 208, 1095.

Amari, S. and Ozima, M. (1988) Extra-terrestrial noble gases in deep-sea sediments. Geochimica et Cosmochimica Acta 52, 1087-1095.

Ballentine, C.J. and Burnard, P.G. (2002) Production, Release and Transport of Noble Gases in the Continental Crust. Rev. Mineral. Geochem 47, 481-538.

Black, D.C. (1972) On the origins of trapped helium, neon and argon isotopic variations in meteorites-I. Gas-rich meteorites, lunar soil and breccia Geochimica et Cosmochimica Acta 36, 347-375.

Bowring, S., Myrow, P., Landing, E., Ramezani , J. and Grotzinger, J. (2003) Geochronological constraints on terminal Neoproterozoic events and the rise of Metazoan. EGS - AGU EUG Joint Assembly, Abstracts from the meeting held in Nice, France, 6 - 11 April 2003 abstract \#13219.

Burns, S.J. and Matter, A. (1993) Carbon isotopic record of the latest Proterozoic from Oman. Eclogae Geologicae Helvetiae 86, 595-607.

Chavrit, D., Moreira, M. and Moynier , F. (2016) Estimation of the extraterrestrial $3 \mathrm{He}$ and $20 \mathrm{Ne}$ fluxes on Earth from $\mathrm{He}$ and $\mathrm{Ne}$ systematics in marine sediments. Earth and Planetary Science Letters 436, 10-18.

Clarke, W.B., jenkins, W.J. and Top, Z. (1976a) Determination of tritium by mass spectrometric measurement of 3He. The International Journal of Applied Radiation and Isotopes 27, $512-$ 522.

Clarke, W.B., Jenkins, W.J. and Top, Z. (1976b) Determination of tritium by mass spectrometric measurement of 3He. Int. J. Appl. radiat. Isot. 27, 515-522.

Condon, D., Zhu, M., Bowring, S., Wang, W., Yang, A. and Jin, Y. (2005) U-Pb Ages from the Neoproterozoic Doushantuo Formation, China. Science 308, 95.

Darrah, T.H. and Poreda, R. (2012) Evaluating the accretion of meteoritic debris and interplanetary dust particles in the GPC-3 sediment core using noble gas and mineralogical tracers. Geochim. Cosmoch. Acta 84, 329-352.

Drescher, J., Kirsten, T. and Schafer, K. (1998) The rare gas inventory of the continental crust, recovered by the KTB continental deep drilling project. Earth and Planetary Science Letters 154, 247-263. 
Eberhardt, P., Eugster, E. and Marti, K. (1965) A redetermination of the isotopic composition of atmospheric neon. Z. Naturforsch. 20a, 623-624.

Eikenberg, J., Signer, P. and Wieler, R. (1993) U-Xe, U-Kr, and U-Pb systematics for dating uranium minerals and investigations of the production of nucleogenic neon and argon. Geochim. Cosmoch. Acta 57, 1053-1069.

Farley, K.A., Shoemaker, E.M., Montanari, A. and Patterson, D.B. (1997) Helium-3 evidence for a comet shower in the late Eocene. Seventh annual V. M. Goldschmidt conference, Tucson, AZ, United States, June 2-6, 1997 LPI Contribution, vol.921, pp.68-69, 1997.

Farley , K.A., Vokrouhlicky, D., Bottke, W.F. and Nesvorny, D. (2006) A late Miocene dust shower from the break-up of an asteroid in the main belt. Nature 439, 295-297.

Fike , D.A., Grotzinger, J.P., Pratt , L.M. and Summons, R.E. (2006) Oxidation of the Ediacaran Ocean. Nature 444, 744-747.

Gautheron, C., tassan-Got, L. and Farley, K.A. (2006) (U-Th)/Ne chronometry. Earth and Planetary Science Letters 243, 520-535.

Gostin, V.A., McKirdy, D.M., Webster, L.J. and Williams, G.E. (2010) Ediacaran ice-rafting and coeval asteroid impact, South Australia: insights into the terminal Proterozoic environment. Australian Journal of Earth Sciences 57, 859-869.

Grotzinger, J.P., Bowring, S.A., Saylor , B.Z. and Kaufman , A.J. (1995) Biostratigraphic and geochronologic constraints on early animal evolution. Science 270, 598.

Grotzinger, J.P., Fike, D.A. and Fischer, W.W. (2011) Enigmatic origin of the largest-known carbon isotope excursion in Earth's history. Nature Geosci 4, 285-292.

Haines, P.W. (2005) Impact cratering and distal ejecta: the Australian record. Australian Journal of Earth Sciences 52.

Hildebrand, A.R., Penfield, G.T., Kring, D.A., Pilkington, M., Camargo Z., A., Jacobsen, S.B. and Boynton, W.V. (1991) Chicxulub Crater: a possible Cretaceous/Tertiary boundary impact crater on the Yucatán Peninsula, Mexico. Geology 19, 867-871.

Hiyagon, H. (1994) Retention of Solar Helium and Neon in IDPs in Deep Sea Sediment. Science $263,1257-1259$.

Holland, G., Sherwood Lollar, B., Li, L., Lacrampe-Couloume, G., Slater, G.F. and Ballentine, C.J. (2013) Deep fracture fluids isolated in the crust since the Precambrian era. Nature 497, 357-360. 
518

519

520

521

522

523

524

525

526

527

528

529

530

531

532

533

534

535

536

537

538

539

540

541

542

543

544

545

546

Hünemohr, H. (1989) Edelgase in U- und Th-reichen Mineralen und die Bestimmung der ${ }^{21} \mathrm{Ne}-$ Dicktarget-Ausbeute der ${ }^{18} \mathrm{O}(\mathrm{a}, \mathrm{n})^{21} \mathrm{Ne}-$ Kernreaktion im Beraich 4.0 - 8.8 MeV. JohannesGutenberg-Universität in Mainz.

Huss, G.R. and Lewis, R. (1994) Noble gases in presolar diamonds II : Component abundances reflect thermal processing. Meteoritics 29, 811-829.

Kennedy, B.M., Hiyagon, H. and Reynolds, J.H. (1990) Crustal neon: a striking uniformity. Earth and Planetary Science Letters 98, 277-286.

Le Guerroué, E. (2010) Duration and synchroneity of the largest negative carbon isotope excursion on Earth: The Shuram/Wonoka anomaly. Comptes Rendus Geoscience 342, 204214.

Le Guerroué, E., Allen, P.A., Cozzi, A., Etienne , J.L. and Fanning , M. (2006) 50 Myr recovery from the largest negative $\delta 13 \mathrm{C}$ excursion in the Ediacaran ocean. Terra Nova 18, 147-153.

Le Guerroué, E. and Cozzi, A. (2010) Veracity of Neoproterozoic negative C-isotope values: the termination of the Shuram negative excursion. Gondwana Research 17, 653-661.

Lippmann-Pipke, J., Sherwood Lollar, B., Niedermann, S., Stroncik, N.A., Naumann , R., van Heerden , E. and Onstott , T.C. (2011) Neon identifies two billion year old fluid component in Kaapvaal Craton. Chem. Geol. 283, 287-296.

Marcantonio, F., Kumar, N., Stute, M., Anderson, R.F., Seidl , M.A., Schlosser , P. and Mix , A. (1995) A comparative study of accumulation rates derived by He and Th isotope analysis of marine sediments. Earth and Planetary Science Letters 133, 549-555.

McGee, D. and Mukhopadhyay, S. (2013) Extraterrestrial He in sediments: from recorder of asteroid collisions to timekeeper of global environmental change. in: Burnard, P.G. (Ed.), The Noble Gases as Geochemical Tracers. Springer Berlin Heidelberg, 155-176.

Moreira, M. (2013) Noble gas constraints on the origin and evolution of earth's volatiles. Geochemical Perspectives 2, 229-403.

Moreira, M. and Allègre, C.J. (2002) Rare gas systematics on Mid Atlantic Ridge $\left(37^{\circ}-40^{\circ}\right)$. Earth and Planetary Science Letters 198, 401-416.

Moreira, M. and Charnoz, S. (2016) Origin of the neon in Earth and in chondrites. Earth and Planetary Science Letters 433, 249-256. 
Mougel , B., Moynier, F., Göpel, C. and Koeberl , C. (2017) Chromium isotope evidence in ejecta deposits for the nature of Paleoproterozoic impactors. Earth and Planetary Science Letters 460, 105-111.

Mukhopadhyay, S., Farley, K.A. and Montanari, A. (2001) A short duration of the CretaceousTertiary boundary event: evidence from extraterrestrial Helium-3. Science 291, 1952-1955.

Murphy, B.H., Farley, K.A. and Zachos, J.C. (2010) An extraterrestrial 3He-based timescale for the Paleocene-Eocene thermal maximum (PETM) from Walvis Ridge, IODP Site 1266. Geochim. Cosmoch. Acta 74, 5098-5108.

Patterson, D.B., Farley, K.A. and Schmitz, B. (1998) Preservation of extraterrestrial 3He in 480Ma-old marine limestones. Earth and Planetary Science Letters 163, 315-325.

Pepin, R.O. (1967) Trapped neon in meteorites. Earth and Planetary Science Letters 2, 13-18.

Peucker-Ehrenbrink , B. (2001) Iridium and osmium as tracers of extraterrestrial matter in marine sediments. in: Peucker-Ehrenbrink, B., Schmitz, B. (Eds.), Accretion of extraterrestrial matter throughout Earth's history. Springer Science+Business Media, New York, 163-178.

Pu, J.P., Bowring, S.A., Ramezani, J., Myrow, P., Raub, T.D., Landing, E., Mills, A., Hodgin, E. and Macdonald, F.A. (2016) Dodging snowballs: geochronology of the Gaskiers glaciation and the first appearance of the Ediacaran biota. Geology.

Schmieder, M., Tohver, E., Jourdan, F., Denyszyn, S.W. and Haines, P.W. (2015) Zircons from the Acraman impact melt rock (South Australia): shock metamorphism, U-Pb and ${ }^{40} \mathrm{Ar} /{ }^{39} \mathrm{Ar}$ systematics, and implications for the isotopic dating of impact events. Geochimica et Cosmochimica Acta 161, 71-100.

Sharpton, V.L., Brent Dalrymple, G., Marin, L.E., Ryder, G., Schuraytz, B.C. and UrrutiaFucugauchi, J. (1992) New links between the Chicxulub impact structure and the Cretaceous/Tertiary boundary. Nature 359, 819-821.

Takayanagi, M. and Ozima, M. (1987) Temporal variation of ${ }^{3} \mathrm{He} /{ }^{4} \mathrm{He}$ ratio recorded in deep-sea sediment cores. Journal of Geophysical Research 92, 12531-12538.

Walter, M.R., Veevers , J.J., Calver , C.R., Gorjan, P. and Hill, A.C. (2000) Dating the 840-544 Ma Neoproterozoic interval by isotopes of strontium, carbon, and sulfur in seawater, and some interpretative models. Precambrian Res. 100, 371-433. 
Williams, G.E. (1986) The Acraman impact structure: source of ejecta in late Precambrian shales, South Australia. Science 233, 200--203.

579 Williams, G.E. (1994) Acraman, South Australia: Australia's largest meteorite impact structure. 580 Proc. Royal Soc. Victoria 106.

581 Yatsevich, I. and Honda, M. (1997) Production of nucleogenic neon in the Earth from natural 582 radioactive decay. Journal of Geophysical Researchs 102, 10291-10298.

583

584 
Figure 1: The noble gas composition as a function of depth. NCF = non-carbonate fraction. Error bars for the isotopic ratios are smaller than or equal to the symbol size when non visible. The $\delta^{13} \mathrm{C}$ carbonates data are from (Fike et al., 2006). Geochronological constraints are from (Bowring et al., 2003; Condon et al., 2005; Fike et al., 2006 ; Grotzinger et al., 1995; Le Guerroué et al., 2006). The Khufai and Shuram formations are separated by an unconformity (wavy curve) that probably includes the Gaskiers glaciation (Bowring et al., 2003). The dotted lines are the limits of the Shuram carbon isotope negative excursion (Fike et al., 2006).

Figure 2: ${ }^{3} \mathrm{He} /{ }^{4} \mathrm{He}$ ratio versus ${ }^{3} \mathrm{He}$ contents. The lines represent mixing lines between an IDP component, rich in ${ }^{3} \mathrm{He}$, with ${ }^{3} \mathrm{He} /{ }^{4} \mathrm{He}=2.4 \times 10^{-4}$ and two hypothetical terrestrial endmembers, rich in radiogenic ${ }^{4} \mathrm{He}$ and poor in ${ }^{3} \mathrm{He}$ considering ${ }^{3} \mathrm{He} /{ }^{4} \mathrm{He}=10^{-9}-10^{-7}$. The 2 mixing lines are derived from (McGee and Mukhopadhyay, 2013). Examples of literature data (small grey dots) are from (Chavrit et al., 2016; Farley et al., 2006; Murphy et al., 2010), and Chavrit et al. (unpublished data).

Figure 3: ${ }^{20} \mathrm{Ne} /{ }^{22} \mathrm{Ne}$ ratios versus ${ }^{21} \mathrm{Ne} / 22 \mathrm{Ne}$ ratios. Sedim. stands for sediments or sedimentary rocks, $\mathrm{mfl}=$ mass fractionation line. The plain lines are nucleogenic trends for different $\mathrm{O} / \mathrm{F}$ ratios (atomic ratios). Cont. crust (=continental crust predicted) is from (Yatsevich and Honda, 1997). The measured crustal fluids trend with a $\mathrm{O} / \mathrm{F}=113$ (Ballentine and Burnard, 2002) is obtained from the nucleogenic trend defined by the crustal fluid data from (Kennedy et al., 1990). The line "KTB" represents the continental crust as sampled by the KTB drill in Germany (Drescher et al., 1998). The slopes of the mixing lines between the air component and the nucleogenic components are a function of the $\mathrm{O} / \mathrm{F}$ ratio (presented as atomic ratios here). The compositions of IDP are close to that of the $\mathrm{Ne}-\mathrm{B}$ value $\left({ }^{20} \mathrm{Ne} /{ }^{22} \mathrm{Ne}=12.73 \pm 0.02\right.$, ${ }^{21} \mathrm{Ne} / 22 \mathrm{Ne}=0.0321 \pm 0.0001$ ) (Moreira, 2013), the Ne-A composition is from (Huss and Lewis, 1994), the air composition is from (Eberhardt et al., 1965). 
615 Figure 4: Slope of the line passing through the air component and a given sample (reflecting the $616 \mathrm{O} / \mathrm{F}$ value) in the three $\mathrm{Ne}$ isotopes diagram (Figure 3 ) as a function of the depth. The unusual 617 Ne composition characterizes a negative spike at the depth $3404 \mathrm{~m}$. The dotted lines indicate the 618 limits of the Shuram excursion (Figure 1).

619

620

621 Figure 5 : Nuclear reactions producing Ne isotopes in the crust.

622

623

624 Figure 6: SEM-EDS mapping of the residual powders (=non-carbonate fractions, NCF) of 625 several samples from this study. All the acquisitions were done with a resolution of $467 \mathrm{~nm} \cdot \mathrm{px}^{-1}$. 626

627 
628 Table 1: Helium and Ne concentrations and isotopic composition of the sedimentary rocks from 629 the Huqf Supergroup and fluorapatites analyzed in this study using the Noblesse mass 630 spectrometer sited at IPGP. Durango fluorapatites were analyzed in 2006 using the ARESIBO 631 mass spectrometer sited at that time in IPGP. Helium and neon concentrations for these three 632 samples cannot be compared to other Durango analyses since these samples were baked under 633 vacuum before analysis.

634 The sample units, depths and lithologies are from (Fike et al., 2006). In the text, the samples 635 names used correspond to their depth of collection in the drill hole ( $2^{\text {nd }}$ column of this table). 636 Dup. = duplicate. $\mathrm{NCF}=$ non-carbonate fractions, corresponding to residual weight/initial weight 637 ratio in percent. *For the sedimentary rocks, the loaded mass is estimated from the residual 638 fraction after leaching. $\mathrm{R}_{\mathrm{A}}$ is the atmospheric ${ }^{3} \mathrm{He} /{ }^{4} \mathrm{He}$ ratio $\left(1.384 \times 10^{-6}\right.$; (Clarke et al., 1976a). 639 The concentrations are expressed in $\mathrm{cm}^{3} \mathrm{STP}_{\mathrm{g}}{ }^{-1}$ of initial mass. Uncertainties are $\pm 5 \%$ on 640 absolute abundances and $\pm 2 \%$ on element ratios. \#indicates the sample with the unusual $\mathrm{Ne}$ 641 composition. 


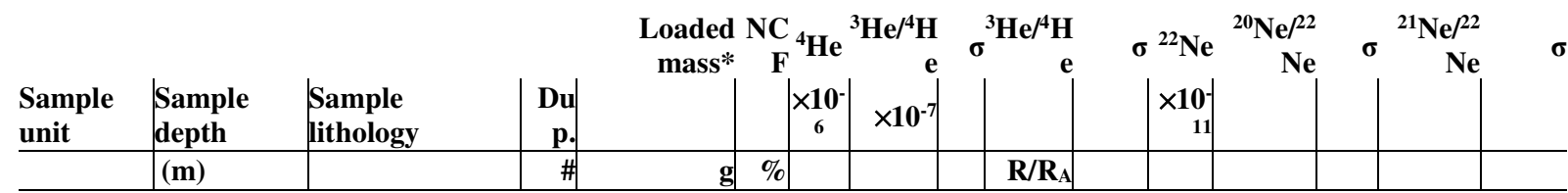

Sedimentary rocks

\begin{tabular}{|c|c|c|c|c|c|c|c|c|c|c|c|c|c|c|c|}
\hline Buah & 3228 & silty dolostone & 1 & 0.1567 & $\begin{array}{r}30 \\
\% \\
\end{array}$ & 7.43 & 0.08 & $\begin{array}{r}0.0 \\
4 \\
\end{array}$ & 0.006 & $\begin{array}{r} \pm 0.00 \\
3 \\
\end{array}$ & 5.31 & 9.45 & \begin{tabular}{|r|} 
\pm 0.0 \\
3 \\
\end{tabular} & 0.0497 & \pm 0.0 \\
\hline & & & 2 & 0.1428 & $\begin{array}{r}30 \\
\%\end{array}$ & 5.33 & 0.48 & \begin{tabular}{|r|}
0.0 \\
5
\end{tabular} & 0.035 & $\begin{array}{r} \pm 0.00 \\
4 \\
\end{array}$ & 5.51 & 9.39 & \begin{tabular}{|r|} 
\pm 0.0 \\
3
\end{tabular} & 0.0477 & \pm 0.0 \\
\hline \multirow[t]{2}{*}{ Buah } & 3320 & silty dolostone & 1 & 0.1449 & $\begin{array}{r}25 \\
\% \\
\end{array}$ & 7.22 & 0.92 & $\begin{array}{r}0.0 \\
7\end{array}$ & 0.067 & $\begin{array}{r} \pm 0.00 \\
5\end{array}$ & 8.77 & 9.79 & \begin{tabular}{|r|} 
\pm 0.0 \\
3
\end{tabular} & 0.0369 & \pm 0.0 \\
\hline & & & 2 & 0.0891 & $\begin{array}{r}25 \\
\% \\
\end{array}$ & 6.57 & 1.09 & $\begin{array}{r}0.0 \\
8 \\
\end{array}$ & 0.079 & $\begin{array}{r} \pm 0.00 \\
6 \\
\end{array}$ & 8.10 & 9.76 & $\begin{array}{r} \pm 0.0 \\
3 \\
\end{array}$ & 0.0365 & \pm 0.0 \\
\hline \multirow[t]{2}{*}{ Buah } & 3360 & dolostone & 1 & 0.1135 & $\begin{array}{r}23 \\
\% \\
\end{array}$ & 1.59 & 2.19 & \begin{tabular}{r|}
0.1 \\
4 \\
\end{tabular} & 0.158 & $\begin{array}{r} \pm 0.01 \\
0 \\
\end{array}$ & 5.59 & 9.79 & \begin{tabular}{|r|} 
\pm 0.0 \\
3 \\
\end{tabular} & 0.0345 & \pm 0.0 \\
\hline & & & 2 & 0.0987 & $\begin{array}{r}23 \\
\% \\
\end{array}$ & 1.99 & 1.11 & \begin{tabular}{r|}
0.1 \\
4 \\
\end{tabular} & 0.081 & \begin{tabular}{|r|}
0.01 \\
0 \\
\end{tabular} & 6.64 & 9.81 & \begin{tabular}{r|} 
\pm 0.0 \\
3 \\
\end{tabular} & 0.0350 & \pm 0.0 \\
\hline \multirow[t]{3}{*}{ Buah } & $3404^{\#}$ & dolostone & 1 & 0.1092 & $\begin{array}{l}13 \\
\% \\
\end{array}$ & 1.58 & 2.97 & $\begin{array}{r}0.1 \\
6 \\
\end{array}$ & 0.214 & $\begin{array}{r} \pm 0.01 \\
1 \\
\end{array}$ & 2.35 & 9.25 & $\begin{array}{r} \pm 0.0 \\
3 \\
\end{array}$ & 0.0370 & \pm 0.0 \\
\hline & & & 2 & 0.1409 & $\begin{array}{r}16 \\
\% \\
\end{array}$ & 1.46 & 3.79 & \begin{tabular}{r|}
0.1 \\
9 \\
\end{tabular} & 0.274 & $\begin{array}{r} \pm 0.01 \\
3 \\
\end{array}$ & 2.37 & 9.13 & \begin{tabular}{|r|} 
\pm 0.0 \\
3 \\
\end{tabular} & 0.0368 & \pm 0.0 \\
\hline & & & 3 & 0.1905 & $\begin{array}{l}16 \\
\% \\
\end{array}$ & 1.59 & 2.92 & $\begin{array}{r}0.1 \\
3 \\
\end{array}$ & 0.211 & $\begin{array}{r} \pm 0.00 \\
9 \\
\end{array}$ & 2.32 & 9.14 & \begin{tabular}{|r|} 
\pm 0.0 \\
3 \\
\end{tabular} & 0.0373 & \pm 0.0 \\
\hline Buah & 3428 & dolostone & 1 & 0.0623 & $\begin{array}{l}11 \\
\% \\
\end{array}$ & 1.11 & 1.62 & $\begin{array}{r}0.0 \\
7 \\
\end{array}$ & 0.117 & $\begin{array}{r} \pm 0.00 \\
5 \\
\end{array}$ & 2.11 & 9.65 & $\begin{array}{r} \pm 0.0 \\
3 \\
\end{array}$ & 0.0401 & \pm 0.0 \\
\hline Shuram & 3480 & silty limestone & 1 & 0.1514 & $\begin{array}{r}19 \\
\% \\
\end{array}$ & 3.31 & 0.52 & \begin{tabular}{|r|}
0.1 \\
5 \\
\end{tabular} & 0.037 & $\begin{array}{r} \pm 0.01 \\
1 \\
\end{array}$ & 5.00 & 9.55 & $\begin{array}{r} \pm 0.0 \\
3 \\
\end{array}$ & 0.0414 & \pm 0.6 \\
\hline \multirow[t]{2}{*}{ Shuram } & 3556 & silty limestone & 1 & 0.1556 & $\begin{array}{r}31 \\
\%\end{array}$ & 2.49 & 1.20 & $\begin{array}{r}0.0 \\
2 \\
\end{array}$ & 0.086 & $\begin{array}{r} \pm 0.00 \\
2 \\
\end{array}$ & 5.04 & 9.34 & $\begin{array}{r} \pm 0.0 \\
7 \\
\end{array}$ & 0.0777 & $\pm 0 .($ \\
\hline & & & 2 & 0.1892 & $\begin{array}{r}31 \\
\% \\
\end{array}$ & 3.40 & 1.33 & $\begin{array}{r}0.0 \\
3 \\
\end{array}$ & 0.096 & $\begin{array}{r} \pm 0.00 \\
2 \\
\end{array}$ & 4.81 & 9.45 & $\begin{array}{r} \pm 0.0 \\
3 \\
\end{array}$ & 0.0788 & \pm 0. \\
\hline Shuram & 3636 & silty limestone & 1 & 0.1534 & $\begin{array}{r}48 \\
\%\end{array}$ & \begin{tabular}{|r|}
18.1 \\
3 \\
\end{tabular} & 0.73 & \begin{tabular}{|r|}
0.1 \\
2
\end{tabular} & 0.052 & $\begin{array}{r} \pm 0.00 \\
9\end{array}$ & 8.13 & 9.05 & $\begin{array}{r} \pm 0.0 \\
3\end{array}$ & 0.0935 & \pm 0.0 \\
\hline Shuram & 3722 & calcareous shale & 1 & 0.1543 & $\begin{array}{r}73 \\
\% \\
\end{array}$ & $\begin{array}{r}21.0 \\
2 \\
\end{array}$ & 0.91 & $\begin{array}{r}0.0 \\
7 \\
\end{array}$ & 0.066 & $\begin{array}{r} \pm 0.00 \\
5 \\
\end{array}$ & \begin{tabular}{|r|}
10.4 \\
2 \\
\end{tabular} & 9.34 & $\begin{array}{r} \pm 0.0 \\
3 \\
\end{array}$ & 0.0898 & \pm 0.0 \\
\hline Shuram & 3780 & silty limestone & 1 & 0.1031 & $\begin{array}{r}52 \\
\%\end{array}$ & 8.41 & 1.14 & $\begin{array}{r}0.0 \\
2\end{array}$ & 0.082 & $\begin{array}{r} \pm 0.00 \\
1\end{array}$ & 6.79 & 9.49 & $\begin{array}{r} \pm 0.0 \\
7\end{array}$ & 0.0782 & \pm 0.0 \\
\hline Shuram & 3826 & $\begin{array}{l}\text { limestone/sandst } \\
\text { one }\end{array}$ & 1 & 0.1476 & $\begin{array}{r}45 \\
\% \\
\end{array}$ & \begin{tabular}{|r|}
10.9 \\
8 \\
\end{tabular} & 2.82 & $\begin{array}{r}0.0 \\
7 \\
\end{array}$ & 0.204 & \begin{tabular}{|r|}
0.00 \\
5 \\
\end{tabular} & 7.76 & 9.56 & $\begin{array}{r} \pm 0.0 \\
3 \\
\end{array}$ & 0.0551 & \pm 0.001 \\
\hline \multirow[t]{2}{*}{ Khufai } & 3900 & dolostone & 1 & 0.1297 & $\begin{array}{r}31 \\
\%\end{array}$ & 6.19 & 1.05 & \begin{tabular}{|r|}
0.0 \\
2
\end{tabular} & 0.076 & $\begin{array}{r} \pm 0.00 \\
2\end{array}$ & 8.71 & 9.73 & $\begin{array}{r} \pm 0.0 \\
7\end{array}$ & 0.0480 & \pm 0.000 \\
\hline & & & 2 & 0.1956 & $\begin{array}{l}31 \\
\% \\
\end{array}$ & 1.70 & 1.01 & \begin{tabular}{|r|}
0.0 \\
2 \\
\end{tabular} & 0.073 & $\begin{array}{r} \pm 0.00 \\
2 \\
\end{array}$ & 2.75 & 9.65 & $\begin{array}{r} \pm 0.0 \\
7 \\
\end{array}$ & 0.0486 & \pm 0.000 \\
\hline Khufai & 3936 & limestone & 1 & 0.1544 & $\begin{array}{r}16 \\
\%\end{array}$ & 7.89 & 0.93 & $\begin{array}{r}0.0 \\
5\end{array}$ & 0.067 & $\begin{array}{r} \pm 0.00 \\
4 \\
\end{array}$ & $\begin{array}{r}14.6 \\
9 \\
\end{array}$ & 9.81 & \begin{tabular}{|r|} 
\pm 0.0 \\
1 \\
\end{tabular} & 0.0356 & \pm 0.000 \\
\hline
\end{tabular}

\section{Durango fluorapatite}

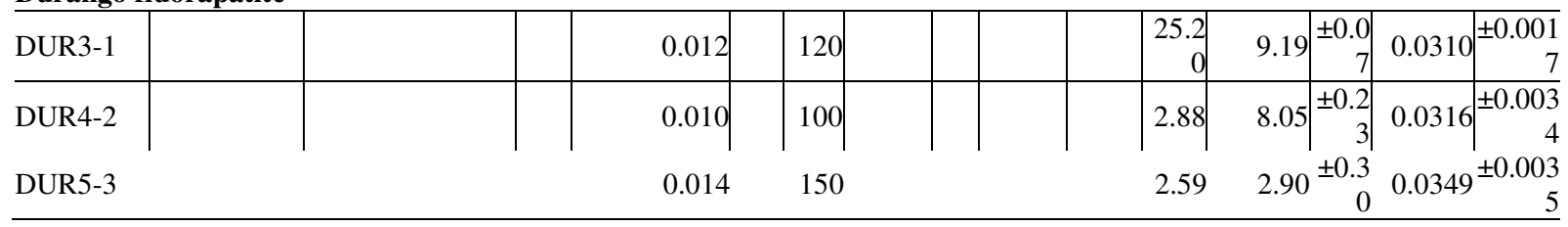




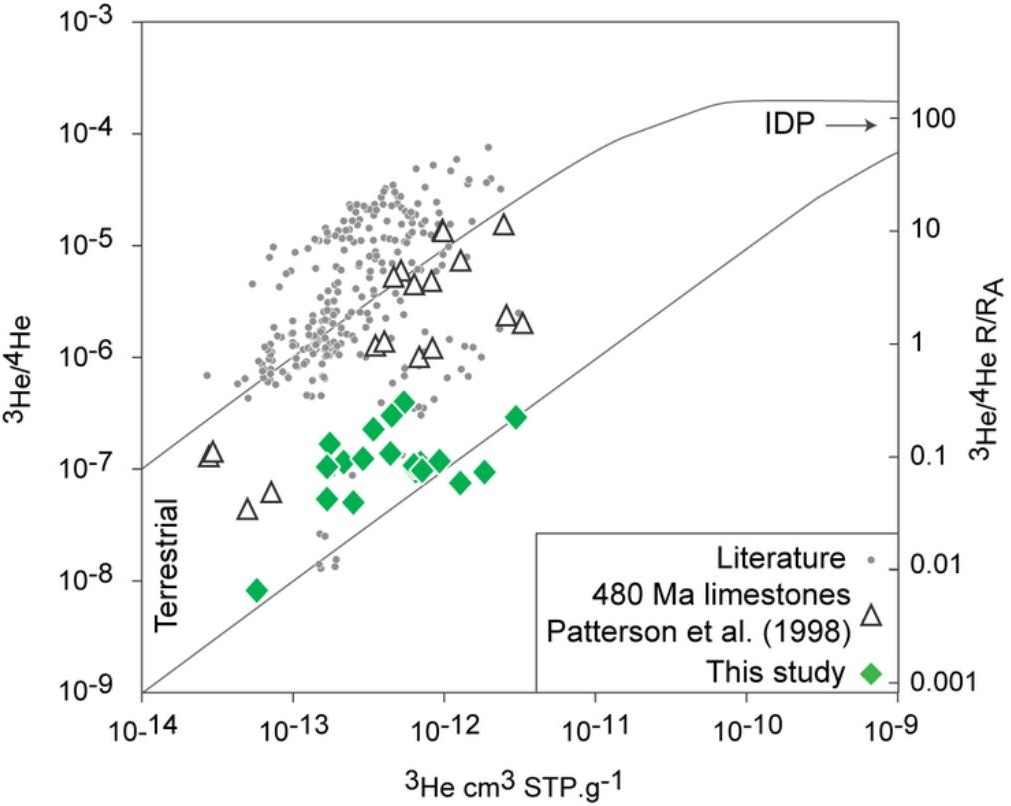




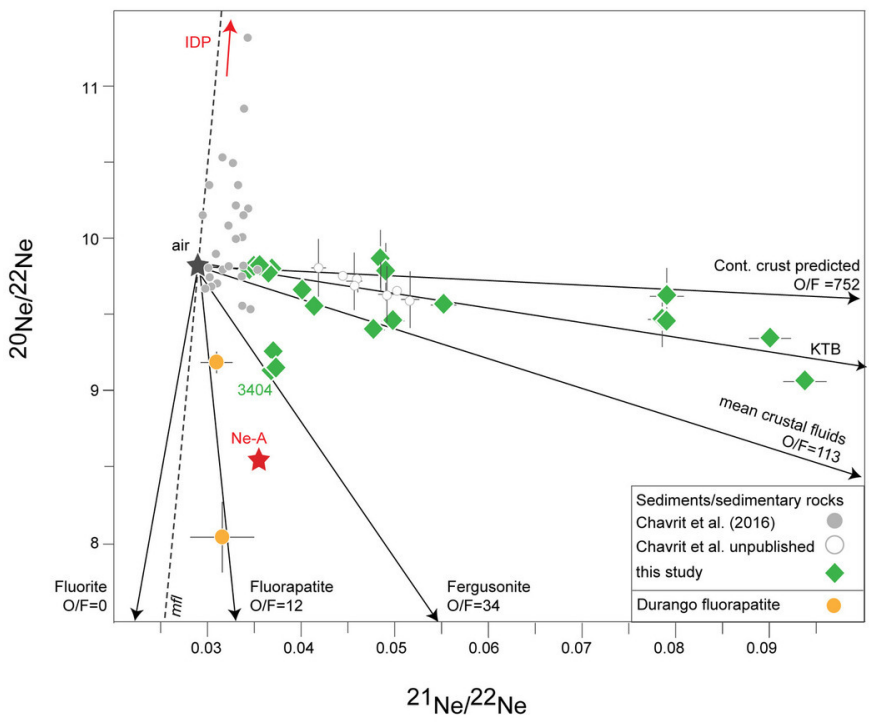


slope of mixing line in Ne diagram

$-100$

$-50$

0

50

$\widehat{\underline{\xi}}$
$\underline{\underline{0}}$
$\bar{\Delta}$

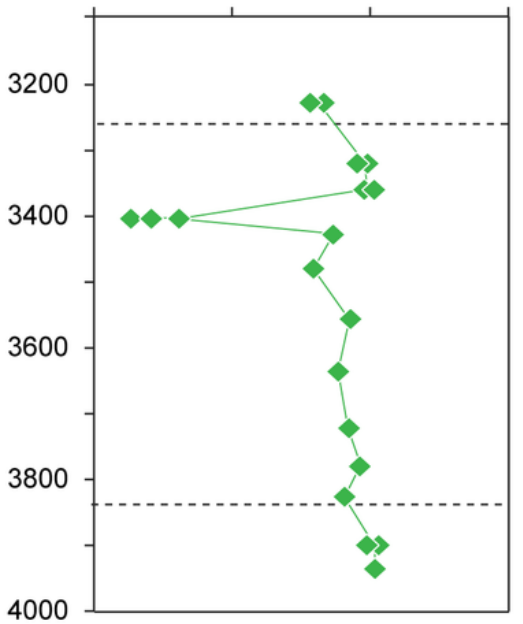




$$
{ }^{235} \mathrm{U},{ }^{238} \mathrm{U},{ }^{232} \mathrm{Th} \rightarrow{ }^{4} \mathrm{He}(\alpha)
$$



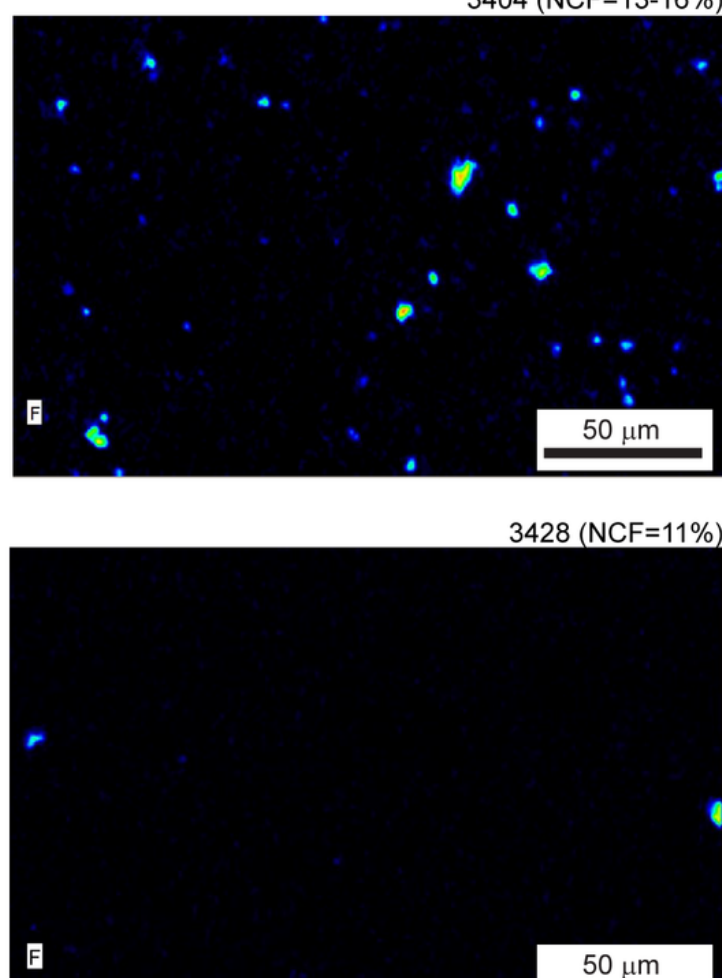

E
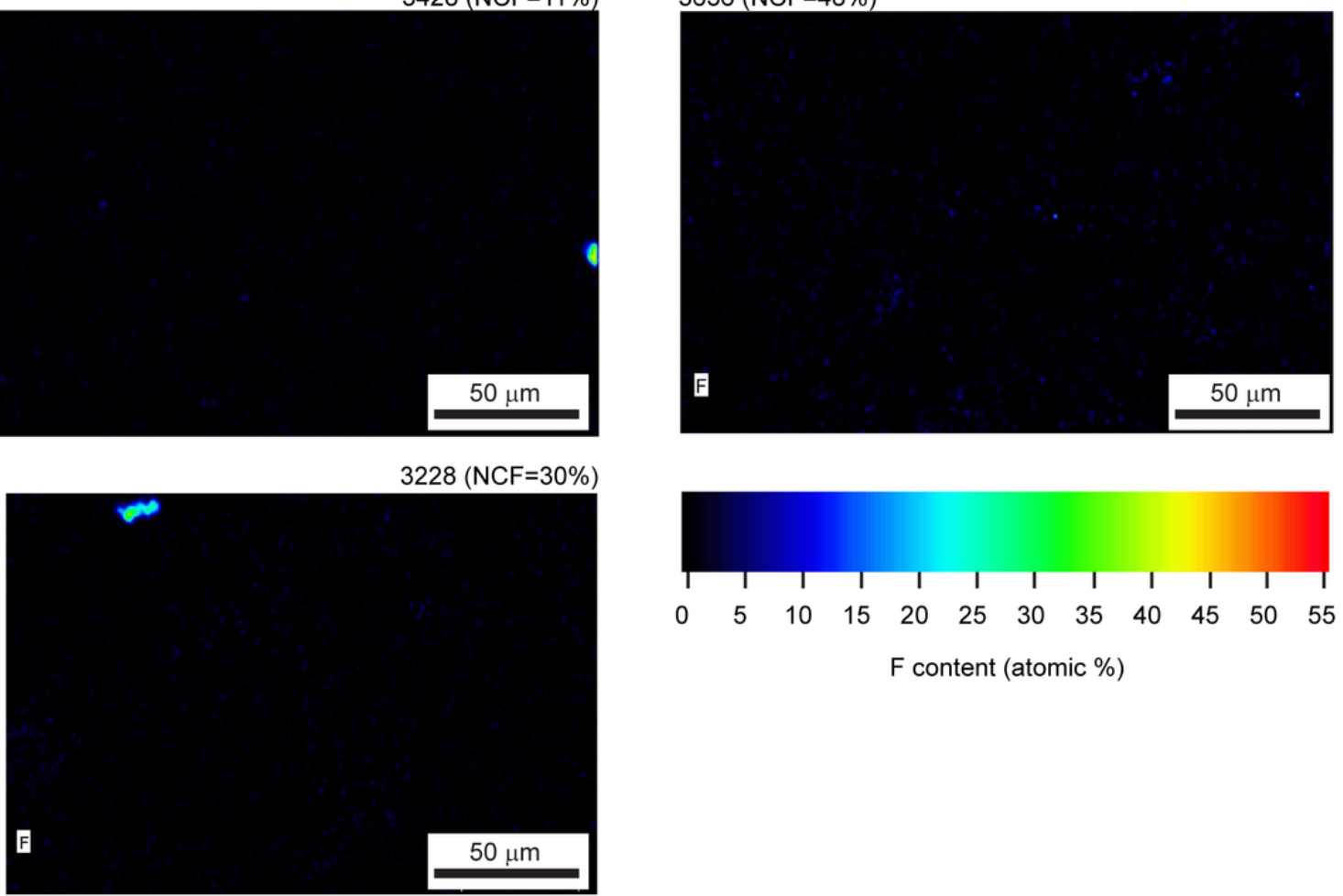